\title{
Genetic Variability, Inter-Relationship and Path Analysis for Seed Yield and it's Contributing Traits in Roselle (Hibiscus sabdariffa L.) Over Six Environments
}

\author{
N. Hari Satyanarayana ${ }^{1 *}$, V. Visalakshmi ${ }^{2}$, Subhra Mukherjee ${ }^{3}$ and S.K. Roy ${ }^{4}$
}

${ }^{1}$ Agricultural Research Station, Amadalavalasa, Srikakulam District, A. P.-532 185, India

${ }^{2}$ Agricultural Research Station, Ragolu, Srikakulam District, A. P.-532 484, India

${ }^{3}$ Bidhan Chandra Krishi Viswavidyalaya, Mohanpur, West Bengal- 741 252, India

${ }^{4}$ Uttar Banga Krishi Viswavidyalaya, Pundibari, Coochbehar, West Bengal-736 165, India

*Corresponding author

\begin{tabular}{|l|}
\hline Ke y w o r d s \\
Correlation, Direct \\
and indirect effects, \\
Genetic advance, \\
Heritability, \\
Roselle, Seed yield \\
\hline Article Info \\
\hline $\begin{array}{l}\text { Accepted: } \\
\text { 06 December } 2017 \\
\text { Available Online: } \\
\text { 10 January } 2018\end{array}$ \\
\hline
\end{tabular}

\section{Introduction}

Roselle (Hibiscus sabdariffa L.) belongs to the family Malvaceae; native to Asia (India to Malaysia) or Africa; and is an annual or biennial plant cultivated in Tropical and SubTropical regions for its stem, fibres, edible calyces, leaves and seeds (Babatunde and Mofoke, 2006; Mahadevan et al., 2009). Roselle is a tetraploid species with $2 \mathrm{n}=4 \mathrm{x}=72$ (Sabiel et al., 2014) and proved its importance in fibre industries, preparation of medicines and in culinaries to make favourable dishes from its edible parts in many countries. Two 
botanical types of roselle viz., Hibiscus sabdariffa var. altissima and Hibiscus sabdariffa var. sabdariffa exists of which var. altissima grown for its phloem fibre and var. sabdariffa for its fleshy calyces (Krishna Murthy et al., 1992; Tejaswini et al., 1995 and Ibrahim et al., 2013). Roselle fibre blended with jute is used in the manufacture of jute goods viz., cordage, sacking, hessian, canvas and rough sacks, ropes, twines, fishing nets etc. The stalks were used in making paper pulp, structural boards, as a blend for wood pulp and thatching huts. The seed contains 18$20 \%$ oil and is used in soap and other industries (Juhi Agarwal and Ela Dedhia, 2014).

Roselle in India is the important bast fibre crop after jute in terms of area and production (Hariram and Appalaswamy, 2014). The major growing states of this crop are Andhra Pradesh, Bihar, Orissa, West Bengal and Maharashtra with an area of 84 thousand ha (during 2012-13) that produced 6.16 lakh bales $(1$ bale $=180 \mathrm{~kg}$ ) with an average productivity of about $13.20 \mathrm{q} / \mathrm{ha}$ (Sen and Karmakar, 2014). Since, roselle is mostly used for its fibre in India, efforts were made only on fibre yield and its contributing traits by researchers till date and there is every need to study on seed yield and its contributing characters also.

Generally, the success of any crop improvement program largely depends on the magnitude of genetic variability, genetic advance, character association, direct and indirect effects on yield and its attributes. Correlation and path coefficient analysis of traits will also help in component characters in a breeding programme whose selection would result in the improvement of complex traits that are positively correlated. Genetic variability and inter-relationship studies have been done in a wide range of fibre crops e.g. kenaf (Mostofa et al., 2002; Echekwu and
Showemino, 2004 and Ghodke and Wadikar, 2011), roselle (Pullibai et al., 2005; Ibrahim and Hussein, 2006; Rani et al., 2006; Bhajantri et al., 2007; Ibrahim et al., (2013) and Satyanarayana et al., 2015), jute (Palve and Sinha, 2005 and Bhattacharya et al., 2007) and okra (Murtadha et al., 2004; Adeniji et al., 2007 and Nwangburuka et al., 2012) will provide the information on genotypic coefficient of variance (GCV), phenotypic coefficient of variance (PCV), heritability, genetic advance and genetic advance as per cent mean (GAM), correlation between different characters with yield along with their direct and indirect effects on yield. In this context, the present investigation was undertaken to assess the genetic variability, heritability and genetic advance, character association and path coefficient analysis of the seed yield and its attributing traits of roselle by utilizing sixty genotypes.

\section{Materials and Methods}

Sixty roselle (Hibiscus sabdariffa L.) genotypes consisting of eleven exotic lines; four released varieties and 45 indigenous accessions were evaluated at three different agro-climatic environments viz., North Coastal zone, Andhra Pradesh at Agricultural Research Station, Ragolu (Latitude $18^{0} 24^{\prime} \mathrm{N}$; Longitude $83.84^{\circ} \mathrm{E}$ at an altitude of $27 \mathrm{~m}$ above mean sea level); Indo-Gangetic zone, West Bengal at Instructional Farm, Bidhan Chandra Krishi Vishwavidyalaya, Jaguli (Latitude $22^{0} 93^{\prime} \mathrm{N}$; Longitude $88.59^{\circ} \mathrm{E}$ at an altitude of $9.75 \mathrm{~m}$ above mean sea level) for first year and at Teaching farm, Mondauri, BCKV (Latitude $22^{0} 87^{\prime} \mathrm{N}$; Longitude 88. $59^{0}$ $\mathrm{E}$ at an altitude of $9.75 \mathrm{~m}$ above mean sea level) for second year and Terai Zone, West Bengal at University Farm, Uttar Banga Krishi Vishwavidyalaya (Latitude $26^{0} \quad 19^{\prime} \quad \mathrm{N}$; Longitude $89.23^{\circ} \mathrm{E}$ at an altitude of $43 \mathrm{~m}$ above mean sea level). The experiments were sown during early kharif seasons in 2013 and 
2014 at the above three zones. The experimental trial was laid out in randomized block design in two replications with a plot size of four rows of $2 \mathrm{~m}$ length with intra-row spacing of $10 \mathrm{~cm}$ and inter-row spacing of 30 $\mathrm{cm}$ accommodating 20 plants in a row. Recommended package of practices was followed to raise a good crop. Data on the basis of five randomly selected plants were recorded for plant height $(\mathrm{cm})$, base diameter (mm), number of nodes per plant, days to $50 \%$ flowering, number of pods per plant, number of seeds per pod, test weight (g) and seed yield per plant $(\mathrm{g})$.

The pooled data were subjected to analysis of variance following standard statistical methods (Singh and Choudhary, 1985). Genotypic and Phenotypic coefficients of variation (GCV and PCV) were calculated using the formula suggested by Burton and De Vane (1953). Heritability and genetic advance were estimated according to the formulae given by Allard (1960). Genotypic and phenotypic correlations were calculated as suggested by Johnson et al., (1955). The phenotypic correlations were used to find out the direct and indirect effects of the component characters on fibre yield per plant, according to Dewey and Lu (1959).

\section{Results and Discussion}

The pooled mean performance of 60 roselle genotypes for eight seed yield related traits from six environments revealed significant difference among the genotypes for all the eight characters (Table 1). Mean data for each character along with range, genotypic coefficient of variance (GCV), phenotypic coefficient of variance (PCV), heritability, genetic advance (GA) and genetic advance as per cent mean (GAM) was given in Table 2 . Plant height ranged from 207.55 to $351.00 \mathrm{~cm}$, base diameter (14.64 to $19.77 \mathrm{~mm})$, nodes per plant (58.00 to 78.85 ), days to $50 \%$ flowering
(161.58 to 182.83$)$, pods per plant (10.08 to 28.48) seeds per pod (23.12 to 32.52), test weight (1.85 to 3.11) and seed yield (5.92 to $13.83 \mathrm{~g}$ ) which showed a wide range of variability for all the characters under study.

The GCV ranged from $5.058 \%$ (days to $50 \%$ flowering) to $33.503 \%$ (pods per plant) among eight traits studied; whereas, PCV ranged from $6.110 \%$ to $49.988 \%$ respectively for characters similar to GCV. Heritability in broad-sense ranged from $16.43 \%$ to $68.55 \%$ for characters test weight and days to $50 \%$ flowering, respectively. Similarly, GAM had a range between $4.539 \%$ to $46.528 \%$ for seeds per pod and pods per plant, respectively.

High values of PCV and GCV were recorded for the traits, pods per plant and seed yield suggesting high variability for these traits in the present study; whereas, the character base diameter exhibited moderate values of GCV and PCV. Days to $50 \%$ flowering showed lower values of GCV and PCV. The traits, plant height, nodes per plant, seeds per pod and test weight had exhibited moderate values for PCV and lower values for GCV which confirms the influence of environment on these traits. These findings are in agreement with Dastidar et al., (1993), Islam et al., (2002), Palve et al., (2003), Echekwu and Showemino (2004), Ibrahim and Hussein (2006), Nwangburuka et al., (2012), Ibrahim et al., (2013) and Hari Satyanarayana et al., (2017). The estimates of PCV were generally higher than their corresponding GCV for all the characters studied suggesting thereby the important role of environment in the expression of these traits. Hence, phenotypic selection may not hold good for genetic improvement in these traits.

Practically, heritability estimates are of greater value to the breeder, since, they indicate the degree of dependence of genotypic value on phenotypic value. Broad-sense heritability was 
high for character days to $50 \%$ flowering only; whereas, medium for most of the characters except seeds per pod and test weight. Similar results were also reported by Dastidar et al., (1993), Mostofa et al., (2002), Echekwu and Showemino (2004), Nwangburuka et al., (2012), Ibrahim et al., (2013) and Hari Satyanarayana et al., (2017). The estimates of heritability, however, indicate only the effectiveness with which the selection of genotypes can be made based on their phenotypic performance, but fail to indicate the amount of progress expected from selection. For an effective selection, the knowledge alone on the estimates of heritability is not sufficient and genetic advance if studied along with heritability is more useful.

Genetic advance as percent of mean was higher for the traits pods per plant and seed yield; whereas, moderate for plant height, base diameter and nodes per plant and lower for the rest of characters. These findings were corroborated with the results of Dastidar et al., (1993), Islam et al., (2002), Nwangburuka et al., (2012), Ibrahim et al., (2013) and Hari Satyanarayana et al., (2017). Greater influence of environment was noticed on the variability parameters of the accessions for different characters can be mainly attributed to the wide range of environments under which the study was undertaken.

\section{Correlation between characters}

The correlation coefficients at genotypic and phenotypic levels were estimated for different pairs of characters from their pooled data of sixty roselle genotypes (Table 3 ). The intercharacter association with seed yield was significant for all characters at phenotypic level, whereas, significant for all characters except for nodes per plant, seeds per pod and test weight at genotypic level. Seed yield was highly significant with pods per plant $(0.953$ and 0.917$)$, base diameter (0.657 and 0.398), plant height $(0.488$ and 0.348$)$ in positive direction, both at genotypic and phenotypic levels; whereas, the trait days to $50 \%$ flowering was highly significant with seed yield in negative direction at both levels. However, the traits, nodes per plant, seeds per pod and test weight were significant positively at phenotypic level only and were nonsignificant at genotypic level.

Selections carried out based on the correlation studies are reliable only when there is significant association both at genotypic and phenotypic levels (Ibrahim and Hussein, 2006) for a particular trait with the dependent variable, yield. High genotypic correlation coefficients than the phenotypic correlation coefficients was observed for all characters suggesting strong relationship between these characters at genetic level.

Seed yield has highly significant positive associations with the traits like pods per plant (0.953 and 0.917), base diameter (0.657 and $0.398)$, plant height (0.488 and 0.348) at genotypic and phenotypic levels; whereas, the trait seeds per pod and test weight were positively significant with seed yield at phenotypic level only. These findings were in agreement with Dastidar et al., (1993), Islam et al., (2001), Palve et al., (2003), Ali and Sasmal (2006), Nwangburuka et al., (2012), Pervin and Haque (2012) and Ibrahim et al., (2013). Plant height exhibited significant positive association with base diameter, nodes per plant, pods per plant and seeds per pod; whereas, base diameter exhibited positive significant association with plant height, nodes per plant and pods per plant. Pods per plant exhibited significant positive correlation with plant height, base diameter and nodes per plant. On the other hand, test weight has significant negative correlation with plant height, base diameter, nodes per plant, days to $50 \%$ flowering and seeds per pod. 
Int.J.Curr.Microbiol.App.Sci (2018) 7(1): 720-732

Table.1 Mean data for seed yield and it's contributing traits of sixty genotypes of roselle (Hibiscus sabdariffa L.)

\begin{tabular}{|c|c|c|c|c|c|c|c|c|c|}
\hline S. No. & Genotype & $\begin{array}{l}\text { Plant } \\
\text { height } \\
\text { (cm) }\end{array}$ & $\begin{array}{c}\text { Base } \\
\text { diameter } \\
(\mathbf{m m})\end{array}$ & $\begin{array}{l}\text { Nodes } \\
\text { / plant }\end{array}$ & $\begin{array}{l}\text { Days to } \\
\text { flowering }\end{array}$ & $\begin{array}{c}\text { Pods } \\
\text { per } \\
\text { plant }\end{array}$ & $\begin{array}{c}\text { Seeds } \\
\text { per } \\
\text { pod }\end{array}$ & $\begin{array}{c}\text { Test } \\
\text { weight } \\
\text { (g) }\end{array}$ & $\begin{array}{l}\text { Seed } \\
\text { yield } \\
(\mathrm{g})\end{array}$ \\
\hline 1 & AR -14 & 304.92 & 19.44 & 71.75 & 165.08 & 18.32 & 29.33 & 2.56 & 10.28 \\
\hline 2 & AR - 19 & 304.13 & 17.70 & 70.33 & 164.67 & 26.13 & 26.40 & 2.33 & 1.86 \\
\hline 3 & AR -42 & 300.18 & 17.54 & 75.75 & 172.75 & 20.77 & 26.88 & 2.00 & 8.90 \\
\hline 4 & AR -45 & 311.46 & 17.19 & 63.58 & 173.25 & 14.78 & 28.73 & 2.27 & 7.58 \\
\hline 5 & AR -48 & 317.89 & 18.01 & 75.33 & 167.58 & 23.75 & 31.43 & 2.15 & 12.32 \\
\hline 6 & AR -50 & 322.17 & 17.79 & 74.25 & 168.33 & 23.38 & 31.28 & 2.14 & 11.85 \\
\hline 7 & AR -55 & 337.49 & 18.98 & 77.33 & 163.92 & 28.48 & 29.98 & 2.19 & 13.83 \\
\hline 8 & AR - 66 & 329.04 & 18.27 & 69.42 & 169.50 & 23.50 & 32.52 & 1.99 & 11.41 \\
\hline 9 & AR - 67 & 324.07 & 18.49 & 75.92 & 168.83 & 26.95 & 30.35 & 2.08 & 12.46 \\
\hline 10 & AR - 71 & 338.09 & 19.32 & 72.67 & 167.33 & 25.60 & 28.33 & 2.54 & 13.65 \\
\hline 11 & AR - 79 & 315.87 & 17.67 & 69.33 & 166.42 & 13.98 & 28.03 & 2.01 & 6.08 \\
\hline 12 & AR -80 & 303.75 & 18.96 & 63.00 & 167.67 & 24.85 & 28.60 & 2.46 & 12.81 \\
\hline 13 & AR -81 & 326.08 & 18.39 & 66.08 & .33 & 20.25 & 29.47 & 2.24 & 10.19 \\
\hline 14 & AR -85 & 286.46 & .67 & 71.00 & 67 & 20.00 & 27.83 & .32 & 9.32 \\
\hline 15 & AR -88 & 325.05 & 17.79 & 63.75 & 172.83 & 15.55 & 29.72 & 2.29 & 8.33 \\
\hline 16 & R - 16 & 322.79 & 18.28 & 65.92 & 168.00 & 21.05 & 28.98 & 2.56 & 11.80 \\
\hline 17 & R - 29 & 340.52 & 19.55 & 71.08 & 168.25 & 17.47 & 29.10 & 2.59 & 10.01 \\
\hline 18 & R 30 & 350.35 & 18.69 & 70.50 & 172.50 & 21.68 & 30.08 & 2.15 & 10.66 \\
\hline 19 & R - 37 & 338.50 & 18.52 & 68.42 & 176.58 & 25.95 & 31.38 & 2.18 & 13.15 \\
\hline 20 & $\mathrm{R}-48$ & 315.75 & 17.74 & 71.33 & 176.00 & 24.52 & 24.03 & 2.59 & 11.13 \\
\hline 21 & R - 67 & 310.86 & 19.50 & 64.25 & 167.92 & 19.20 & 26.85 & 2.49 & 9.25 \\
\hline 22 & R - 68 & 312.23 & 18.54 & 74.67 & 176.17 & 25.30 & 28.45 & 2.25 & 11.86 \\
\hline 23 & R - 77 & 299.57 & 16.13 & 67.17 & 175.67 & 15.45 & 28.30 & 2.17 & 7.28 \\
\hline 24 & R - 86 & 351.00 & 18.94 & 78.58 & 168.58 & 22.20 & 30.47 & 2.14 & 11.05 \\
\hline 25 & R - 134 & 299.25 & 19.43 & 69.58 & 177.50 & 23.03 & 29.98 & 2.39 & 12.45 \\
\hline 26 & R - 180 & 322.57 & 19.51 & 71.42 & 178.17 & 21.93 & 26.38 & 2.29 & 10.68 \\
\hline 27 & $R-225$ & 328.82 & 19.57 & 65.42 & 173.33 & 24.63 & 23.58 & 2.40 & 10.29 \\
\hline 28 & R - 243 & 293.67 & 17.91 & 60.50 & 167.58 & 16.65 & 30.22 & 2.39 & 9.11 \\
\hline 29 & R - 271 & 336.78 & 18.68 & 68.42 & 175.67 & 20.13 & 31.80 & 1.97 & 9.57 \\
\hline
\end{tabular}




\begin{tabular}{|c|c|c|c|c|c|c|c|c|c|}
\hline 30 & R - 284 & 341.67 & 19.77 & 69.08 & 174.08 & 23.30 & 32.50 & 2.02 & 11.10 \\
\hline 31 & $R-318$ & 336.53 & 17.76 & 73.92 & 173.00 & 20.33 & 29.83 & 2.08 & 9.68 \\
\hline 32 & $R-322$ & 295.21 & 17.43 & 68.75 & 175.67 & 16.18 & 27.07 & 1.85 & 6.60 \\
\hline 33 & ER - 56 & 312.98 & 17.92 & 71.08 & 173.00 & 18.43 & 31.25 & 2.04 & 8.93 \\
\hline 34 & ER - 57 & 320.66 & 18.16 & 66.67 & 170.17 & 21.07 & 28.98 & 2.24 & 10.35 \\
\hline 35 & ER - 60 & 207.55 & 14.91 & 58.00 & 163.67 & 13.60 & 28.60 & 2.65 & 7.80 \\
\hline 36 & ER - 68 & 293.52 & 16.54 & 67.67 & 176.92 & 20.98 & 29.38 & 2.08 & 9.74 \\
\hline 37 & AS - $80-6$ & 306.57 & 18.64 & 67.25 & 166.67 & 17.37 & 28.12 & 2.33 & 8.80 \\
\hline 38 & AS - $80-7$ & 328.70 & 19.20 & 69.08 & 172.83 & 19.95 & 28.87 & 2.57 & 10.96 \\
\hline 39 & AS - $80-$ & 253.18 & 16.16 & 67.83 & 166.58 & 17.45 & 26.47 & 2.69 & 9.30 \\
\hline 40 & AS - $80-$ & 246.68 & 15.81 & 63.08 & 170.83 & 13.17 & 28.17 & 2.13 & 6.23 \\
\hline 41 & AS - 80 - & 283.95 & 17.61 & 67.00 & 175.58 & 18.08 & 30.57 & 2.61 & 10.83 \\
\hline 42 & $\widehat{A S}-81-1$ & 293.02 & 17.10 & 64.83 & 168.92 & 12.98 & 24.69 & 2.42 & 5.92 \\
\hline 43 & AS - $81-2$ & 250.49 & 16.08 & 63.58 & 165.50 & 15.67 & 23.12 & 2.84 & 7.63 \\
\hline 44 & AS - $81-3$ & 308.59 & 17.35 & 62.08 & 174.67 & 19.02 & 29.58 & 2.35 & 10.04 \\
\hline 45 & AS - $81-5$ & 289.07 & 17.39 & 59.33 & 168.17 & 18.07 & 28.00 & 2.49 & 9.77 \\
\hline 46 & AS - $81-9$ & 295.48 & 18.27 & 66.33 & 168.58 & 24.72 & 27.23 & 2.43 & 12.65 \\
\hline 47 & AS - $81-$ & 288.49 & 16.48 & 64.92 & 174.83 & 24.25 & 28.70 & 1.88 & 10.10 \\
\hline 48 & AS - $81-$ & 291.94 & 17.97 & 70.50 & 172.58 & 26.19 & 25.93 & 2.39 & 12.00 \\
\hline 49 & AS - $81-$ & 217.33 & 14.64 & 58.58 & 166.08 & 16.02 & 26.37 & 2.70 & 8.82 \\
\hline 50 & REX - 6 & 315.73 & 18.48 & 67.42 & 166.00 & 24.68 & 28.07 & 2.20 & 11.31 \\
\hline 51 & REX - 14 & 317.12 & 18.63 & 68.67 & 178.42 & 24.10 & 31.45 & 1.98 & 11.08 \\
\hline 52 & REX - 34 & 207.99 & 16.92 & 70.92 & 161.58 & 10.08 & 26.70 & 3.11 & 6.50 \\
\hline 53 & REX - 38 & 249.60 & 16.65 & 65.42 & 174.42 & 11.43 & 30.67 & 2.01 & 5.95 \\
\hline 54 & REX - 45 & 294.50 & 17.07 & 66.17 & 182.83 & 18.58 & 29.35 & 2.18 & 9.27 \\
\hline 55 & REX - 52 & 307.28 & 17.65 & 68.83 & 175.08 & 23.65 & 31.07 & 1.97 & 10.65 \\
\hline 56 & REX - 63 & 294.93 & 17.00 & 65.58 & 167.25 & 22.12 & 28.98 & 2.22 & 10.69 \\
\hline 57 & HS - 4288 & 330.41 & 18.31 & 64.33 & 173.42 & 21.08 & 32.18 & 1.98 & 10.13 \\
\hline 58 & AMV - 4 & 328.30 & 17.45 & 68.92 & 170.42 & 21.03 & 26.62 & 2.14 & 9.00 \\
\hline 59 & AMV - 5 & 330.01 & 17.96 & 64.83 & 170.50 & 19.90 & 31.38 & 2.25 & 10.73 \\
\hline \multirow[t]{3}{*}{60} & AMV - 7 & 324.79 & 19.07 & 67.25 & 170.67 & 22.05 & 31.22 & 2.09 & 10.90 \\
\hline & Mean & 305.53 & 17.93 & 68.08 & 170.93 & 20.35 & 28.83 & 2.28 & 10.04 \\
\hline & C.D. $5 \%$ & 14.17 & 1.2 & 5.72 & 2.89 & 2.29 & 1.26 & 0.11 & 0.97 \\
\hline
\end{tabular}


Table. 2 Genetic variability parameters in roselle (Hibiscus sabdariffa L.) for seed yield and its contributing characters

\begin{tabular}{|c|c|c|c|c|c|c|c|}
\hline Character & Mean & Range & GCV (\%) & PCV (\%) & Heritability & $\begin{array}{l}\text { Genetic } \\
\text { advance }\end{array}$ & GAM \\
\hline Plant height (cm) & 305.53 & $207.55-351.00$ & 9.238 & 14.590 & 40.09 & 36.816 & 12.050 \\
\hline $\begin{array}{l}\text { Base diameter } \\
(\mathrm{mm})\end{array}$ & 17.93 & $14.64-19.77$ & 11.520 & 16.849 & 46.75 & 2.909 & 16.226 \\
\hline Nodes / plant & 68.08 & $58.00-78.58$ & 8.577 & 14.893 & 33.17 & 6.928 & 10.176 \\
\hline $\begin{array}{l}\text { Days to } 50 \% \\
\text { flowering }\end{array}$ & 170.93 & $161.58-182.83$ & 5.058 & 6.110 & 68.55 & 14.747 & 8.627 \\
\hline Pods per plant & 20.35 & $10.08-28.48$ & 33.503 & 49.988 & 44.92 & 9.414 & 46.528 \\
\hline Seeds per pod & 28.83 & $23.12-32.52$ & 5.302 & 12.756 & 17.27 & 1.309 & 4.539 \\
\hline Test weight (g) & 2.28 & $1.85-3.11$ & 5.949 & 14.676 & 16.43 & 0.113 & 4.967 \\
\hline Seed yield (g) & 10.04 & $5.92-13.83$ & 27.238 & 47.317 & 33.14 & 3.244 & 32.299 \\
\hline
\end{tabular}


Table.3 Genotypic and Phenotypic correlation coefficients between seed yield and its component characters in roselle (Hibiscus sabdariffa L.)

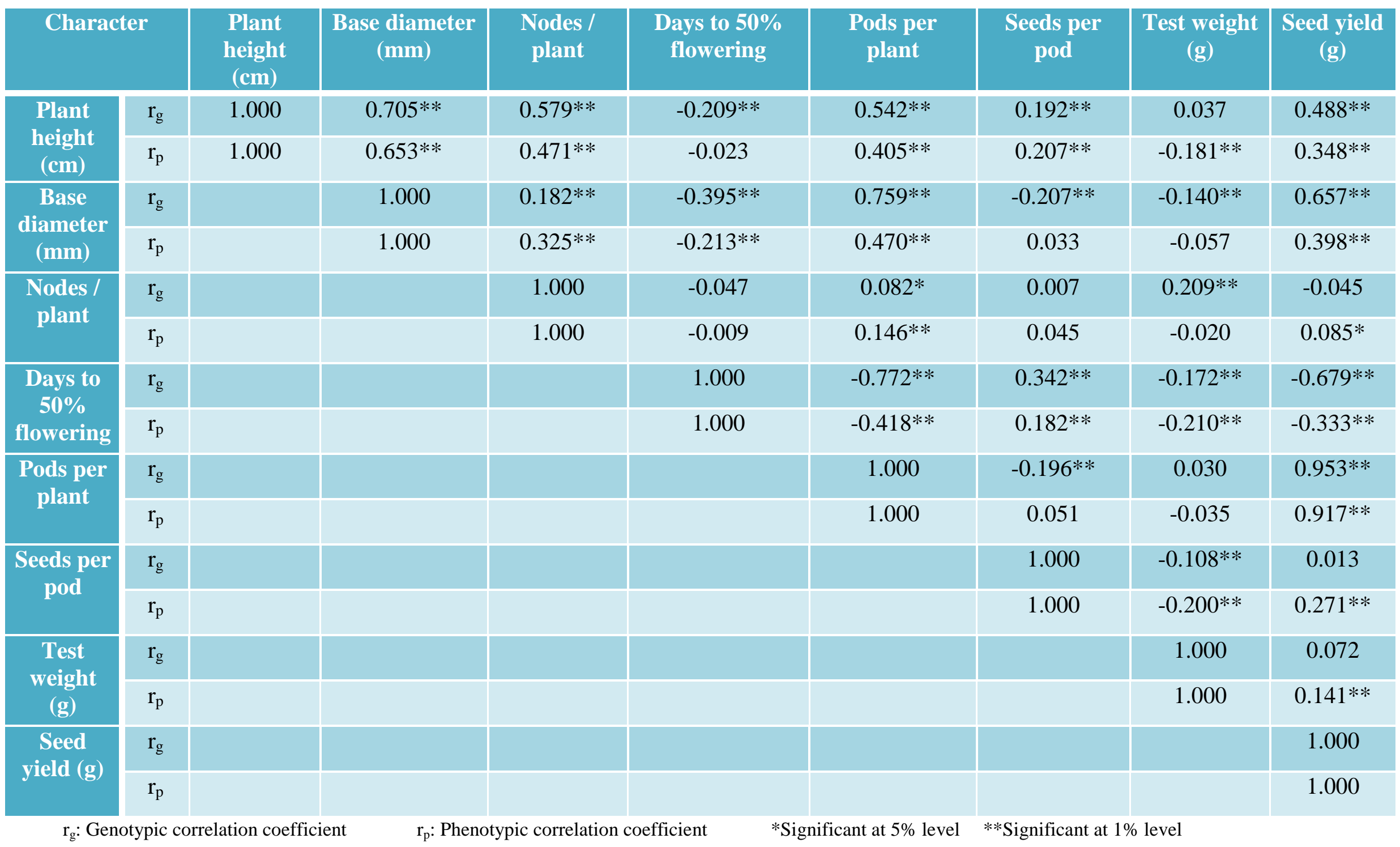


Table.4 Direct and indirect contributions of component characters for seed yield in roselle (Hibiscus sabdariffa L.)

\begin{tabular}{|c|c|c|c|c|c|c|c|c|c|}
\hline \multicolumn{2}{|c|}{ Character } & \multirow{2}{*}{$\begin{array}{c}\text { Plant } \\
\text { height (cm) } \\
\text {-0.0399 }\end{array}$} & \multirow{2}{*}{$\begin{array}{c}\text { Base diameter } \\
\text { (mm) } \\
-0.0695\end{array}$} & \multirow{2}{*}{$\begin{array}{c}\text { Nodes / } \\
\text { plant } \\
-0.0684\end{array}$} & \multirow{2}{*}{$\begin{array}{l}\text { Days to } \\
\text { flowering } \\
-0.0321\end{array}$} & \multirow{2}{*}{$\begin{array}{l}\text { Pods per } \\
\text { plant } \\
0.6569\end{array}$} & \multirow{2}{*}{$\begin{array}{c}\text { Seeds } \\
\text { per pod } \\
0.0378\end{array}$} & \multirow{2}{*}{$\begin{array}{c}\text { Test weight } \\
(\mathrm{g}) \\
0.0035\end{array}$} & \multirow{2}{*}{$\begin{array}{c}\text { Correlation } \\
\text { with seed } \\
\text { yield } \\
0.488 * *\end{array}$} \\
\hline Plant & G & & & & & & & & \\
\hline$(\mathrm{cm})$ & $\mathrm{P}$ & -0.0230 & -0.0002 & -0.0235 & -0.0016 & 0.3842 & 0.0545 & -0.0428 & $0.348 * *$ \\
\hline \multirow{2}{*}{$\begin{array}{c}\text { Base } \\
\text { diameter } \\
(\mathbf{m m})\end{array}$} & G & -0.0282 & -0.0985 & -0.0216 & -0.0607 & 0.9201 & -0.0406 & -0.0133 & $0.657 * *$ \\
\hline & $\mathrm{P}$ & -0.0150 & -0.0003 & -0.0162 & -0.0144 & 0.4497 & 0.0086 & -0.0135 & $0.398 * *$ \\
\hline \multirow{2}{*}{$\begin{array}{c}\text { Nodes / } \\
\text { plant }\end{array}$} & G & -0.0231 & -0.0180 & -0.1182 & -0.0072 & 0.0996 & 0.0015 & 0.0200 & -0.045 \\
\hline & $\mathrm{P}$ & -0.0108 & -0.0001 & -0.0498 & -0.0006 & 0.1396 & 0.0119 & -0.0048 & $0.085^{*}$ \\
\hline \multirow{2}{*}{$\begin{array}{l}\text { Days to } \\
\text { flowering }\end{array}$} & G & 0.0084 & 0.0390 & 0.0055 & 0.1536 & -0.9358 & 0.0672 & -0.01648 & $-0.679 * *$ \\
\hline & $\mathrm{P}$ & 0.0005 & 0.0001 & 0.0005 & 0.0678 & -0.3997 & 0.0479 & -0.0496 & $-0.333 * *$ \\
\hline \multirow{2}{*}{$\begin{array}{c}\text { Pods per } \\
\text { plant }\end{array}$} & G & -0.0216 & -0.0748 & -0.0097 & -0.1185 & 1.2128 & -0.0384 & 0.0029 & $0.953 * *$ \\
\hline & $\mathrm{P}$ & -0.0092 & -0.0001 & -0.0073 & -0.0283 & 0.9571 & 0.0135 & -0.0082 & $0.917 * *$ \\
\hline \multirow{2}{*}{$\begin{array}{c}\text { Seeds per } \\
\text { pod }\end{array}$} & G & -0.0077 & 0.0204 & -0.0009 & 0.0525 & -0.2371 & 0.1964 & -0.0103 & 0.013 \\
\hline & $\mathrm{P}$ & -0.0048 & 0.0001 & -0.0023 & 0.0123 & 0.0490 & 0.2635 & -0.0473 & $0.271 * *$ \\
\hline \multirow{2}{*}{$\begin{array}{c}\text { Test } \\
\text { weight } \\
\text { (g) }\end{array}$} & G & 0.0015 & 0.0138 & -0.0247 & -0.0265 & 0.0362 & -0.0212 & 0.0956 & 0.072 \\
\hline & $\mathrm{P}$ & 0.0042 & 0.0001 & 0.0010 & -0.0143 & -0.0333 & -0.0528 & 0.2362 & $0.141 * *$ \\
\hline
\end{tabular}


With this study, it is confirmed that the traits plant height, base diameter, pods per plant and seeds per pod very important for seed yield as they showed highly significant positive correlation both at genotypic and phenotypic levels for most of the characters. Selections made based on these traits will be successful for higher seed yield in roselle.

\section{Path analysis studies}

Partitioning of correlation coefficients (both at genotypic and phenotypic levels) of various component characters with seed yield into direct and indirect contributions (Table 4) revealed that pods per plant has maximum direct effect (1.2128 and 0.9571) on seed yield followed by seeds per pod $(0.1964$ and $0.2635)$, days to $50 \%$ flowering $(0.1536$ and $0.0678)$ and test weight (0.0956 and 0.2362).

The high correlation coefficient of pods per plant (0.953 and 0.917 at genotypic and genotypic levels) with seed yield was totally due to the direct effects of pods per plant (1.2128 and 0.9571). The high correlation coefficient of base diameter (0.657 and 0.398) with seed yield was majorly due to the indirect effects of pods per plant (0.9201 and 0.4497). Likewise, the high correlation coefficient of plant height (0.488 and 0.348) with seed yield was also largely due to the indirect effects of pods per plant (0.6569 and 0.3842). Similarly, the high correlation coefficient of seeds per plant (0.271) at phenotypic level with seed yield was due to the direct effects of its own (0.2635). The direct effect of test weight (0.2362) at phenotypic level is solely responsible for highly significant correlation of test weight with seed yield. The negative correlation coefficient of days to $50 \%$ flowering at both levels (-0.679 and -0.333) was mainly due to the indirect effect of pods per plant $(-0.9358$ and -0.3997) in spite of the trait itself had a positive direct effect (0.1536 and 0.0678).
The relationship between traits explained through character association studies may not provide a clear picture of bonding between yield and its contributing traits. Path analysis provides lucid information of direct and indirect effects of traits and measures the relative importance of each and every trait in shaping the final objective, seed yield. The direct and indirect effects both at genotypic and phenotypic levels showed that pods per plant (1.2128 and 0.9571) had maximum direct effect followed by seeds per pod (0.1964 and 0.2635$)$, days to $50 \%$ flowering $(0.1536$ and 0.0678$)$ and test weight $(0.0956$ and 0.2362 ), respectively; whereas, nodes per plant has negative direct effect (-0.1182 and $0.0498)$. The positive and highly significant correlation of plant height and base diameter with seed yield were also mainly due to indirect effect of pods per plant rather than their direct effects. These results were corroborated with the findings of Dastidar et al., (1993), Islam et al., (2001), Echekwu and Showemino (2004) and Pervin and Haque (2012).

The value of residual effects was very low, $1.87 \%$ (genotypic correlation) and $5.22 \%$ (phenotypic correlation) suggesting that about $98 \%$ of genotypic total variation and $95 \%$ of phenotypic total variation for seed yield in roselle was explained and the remaining percent have not been studied in the present study. Finally, the path coefficient analysis revealed importance of pods per plant, seeds per pod and test weight for their contribution either directly or indirectly to seed yield and hence, during selection these traits should be given utmost attention for developing of high seed yielding roselle varieties.

In conclusion, selection based on the trait pods per plant proves very effective as the trait showed highest association with seed yield and have high positive direct effect and indirect effects through plant height and base 
diameter coupled with high GCV, PCV, medium heritability and high genetic gain along with seed yield. The other traits, such as plant height and base diameter may also be considered for selection as they have high positive association with seed yield both at genotypic and phenotypic levels. Therefore, emphasis should be given to the above traits during selection for evolving high seed yielding lines of roselle.

\section{Acknowledgement}

The authors are highly thankful to the authorities of ANGRAU, BCKV, UBKV and ICAR-CRIJAF for providing necessary infrastructural facilities to undertake these studies.

\section{References}

Adeniji, O. T. and Aremu, C. O. 2007. Interrelationship among characters and path analysis for pod yield components in West African Okra [Abelmoschus caillei (A. Chev.) Stevels]. Jornal of Agronomy 6(1): 162-166.

Ali, M. N. and Sasmal, B. G. 2006. Association of seed yield and its components in segregating population of tossa jute (Corchorus olitorius). Agricultual Science Digest 26(3): 206208.

Allard, R. W. 1960. Principles of Plant Breeding. John Willey and Sons, Inc. London. pp. 83-108.

Babatunde, F. E. and Mofoke, A. L. E. 2006. Performance of roselle (Hibiscus sabdariffa L.) as influenced by irrigation schedules. Pakistan Journal of Nutrition 5(4): 363-367.

Bhajantri, C. M., Mummigatti, U. V. and Doddamani, M. B. 2007. Correlation studies in Mesta genotypes. Karnataka Journal of Agricultural Sciences 20(2): 368-369.
Bhattacharya, C., Karmakar, K. S. and Bakshi, A. 2007. Study on genetic variability in capsularis jute at different population levels: A comparative study. Journal of Interacademicia 11(4): 393399.

Burton, G. and De Vane, E. H. 1953. Estimating heritability in tall fescue (Festuca arundinacea) from replicated clonal material. Agronomy Journal 45: 478-481.

Dastidar, K. K. G., Agarwalla, K. K. and Roychowdhury, P. 1993. Genetic variability and association component characters for seed yield in Olitorius jute. Indian Journal of Genetics and Plant Breeding 53(2): 157-160.

Dewey, D. R. and Lu, K. H. 1959. A correlation and path coefficient analysis of components of crested wheat grass seed production. Agronomy Journal 51: 515-518.

Echekwu, C. A. and Showemimo, F. A. 2004. Genetic, Phenotypic and environmental variances and character association in kenaf. African Crop Science Journal 12(4): 321-326.

Ghodke, M. K. and Wadikar, P. B. 2011. Estimates of genetic variation and heritability for yield and its attributes in kenaf (Hibiscus cannabinus L.). Research Journal of Agricultural Sciences 2(3): 737-739.

Hari Satyanarayana, N., Visalakshmi, V., Ramana Murthy, K. V., Madhu Kumar, K., Rao, A. U. and Rao, N. V. 2017. Genetic Variability, Heritability and Genetic Advance for Seed Yield and Its Components in Roselle (Hibiscus sabdariffa L.) in North Coastal Zone of Andhra Pradesh, India. Int. J. Curr. Microbiol. App. Sci. 6(5): 242-248.

Hariram, K. B. and Appalaswamy, A. 2014. Principal component and cluster analysis of fibre yield in roselle (Hibiscus sabdariffa L.). International 
Journal of Agriculture, Environment and Biotechnology 7(2): 255-260.

Ibrahim, E. B., Abdalla, A. W. H., Ibrahim, E. A. and Naim, A. M. E. 2013. Variability in some roselle (Hibiscus sabdariffa $\mathrm{L}$.) genotypes for yield and its attributes. International Journal of Agriculture and Forestry 3(7): 261-266.

Ibrahim, M. M. and Hussein, R. M. 2006. Variability, heritability and genetic advance in some genotypes of roselle (Hibiscus sabdariffa L.). World Journal of Agricultural Sciences 2(3): 340-345.

Islam, M. R., Islam, M. M., Akter, N. and Ghosh, R. K. 2002. Genetic variability and performance of tossa jute (Corchorus oiltorius L.). Pakistan Journal of Biological Sciences 5(7): 744-745.

Islam, M. S, Uddin, M. N., Haque, M. M. and Islam, M. N. 2001. Path coefficient analysis for some fibre yield related traits in white jute (Corchorus capsularis L.). Pakistan Journal of Biological Sciences 4(1): 47-49.

Johnson, H. W., Robinson, H. F. and Comstock, R. F. 1955. Estimates of genetic and environmental variability in soybean. Agronomy Journal 47: 314-8.

Juhi Agarwal and Ela Dedhia 2014. Current scenario of Hibiscus sabdariffa (Mesta) in India (Maharastra). The International Journal of Social Sciences and Humanities Invention 1(3): 129-135.

Krishna Murthy, N., Hunsagi, G., Singlachar, M. A. and Rudraradhya, M. 1992. Influence of plant density and nitrogen levels on mesta: Growth components, dry matter and biomass yields. Mysore Journal of Agricultural Research 26: 239-243.

Mahadevan, N., Shivali and Pradeep, K. 2009. Hibiscus sabdariffa Linn. - An overview. Natural Product Radiance 8(1): 77-83.

Mostofa, M. G., Islam, M. R., Morshed Ala,
A. T. M., Ali, S. M. M. and Mollah, M. A. F. 2002. Genetic variability, heritability and correlation studies in kenaf (Hibiscus cannabinus L.). Online Journal of Biological Sciences 2: 442444.

Murtadha, S., Ariyo, O. J. and Kehinde, O. B. 2004. Character association of seed yield and its components in okra [Abelmoschus esculentus (L.) Moench]. Ogun Journal of Agricultural Sciences 3(1): 222-233.

Nwangburuka, C. C., Denton, O. A., Kehinde, O. B., Ojo, D. K. and Popoola, A. R. 2012. Genetic variability and heritability in cultivated okra [Abelmoschus esculentus (L.) Moench]. Span Journal of Agricultural Research 10(1): 123-129

Palve, S. M. and Sinha, M. K. 2005. Genetic variation and interrelationships among fibre yield attributes in secondary genepool of Corchorus spp. SABRAO Journal of Breeding and Genetics 37(1): 55-64.

Palve, S. M., Kumar, D., Chaudhury, S. K. and Gupta, D. 2003. Genetic variation for seed yield in jute (Corchorus spp.). Indian Journal of Genetics and Plant Breeding 63(3): 235-238.

Pervin, N. and Haque, G. K. 2012. Path coefficient analysis for fibre yield related traits in Deshi jute (Corchorus capsularis L.). IRJALS 1(3): 72-77.

Pullibai, P., Razia Sultana, Panduranga Rao, C. and Srinivasa Rao, V. 2005. Character association and path analysis in Roselle hemp (Hibiscus sabdariffa L.). The Andhra Agricultural Journal 52(3\&4): 403-406.

Rani, Ch., Rama Kumar, P. V., Panduranga Rao, C. and Srinivasa Rao, V. 2006. Character association, path analysis and selection indices in roselle (Hibiscus sabdariffa L.). The Andhra Agricultural Journal 53(3\&4): 157-159. 
Sabiel, S. A. I., Ismail, M. I., Osman, A. and Sun, D. 2014. Genetic variability for yield and related attributes of roselle (Hibiscus sabdariffa L.) genotypes under rainfed condition in a Semi-arid zone of Sudan. Persian Gulf Crop Protection 3(1): 33-40.

Satyanarayana, N. H., Subhra Mukherjee, Bhanu Priya and Roy S. 2015. Genetic variability and Inter-relationship between fibre yield and its components in Roselle (Hibiscus sabdariffa L.) in Terai zone of West Bengal. Vegetos 28(3): 135-140.

Sen, H. S. and Karmakar, P. G. 2014. PublicPrivate Partnership from the perspectives of CRIJAF for development of Jute and Allied Fibres. Today's natural fibres for tomorrow, Proc Int Conf on Natural Fibres, held on 1-3 August, 2014 organized by The Indian Natural Fibre Society, Kolkata pp: 40-44.

Singh, R. K. and Choudhary, B. D. 1985. Biometrical Methods in Quantitative Genetic Analysis. Kalyani Publishers, Ludhiana.

Tejaswini, Sheriff, R. A. and Sarma, M. S. 1995. Heterosis, potence ratio and inbreeding depression in roselle (Hibiscus sabdariffa var. altissima). Indian Journal of Genetics and Plant Breeding 55(4): 359-361.

\section{How to cite this article:}

Hari Satyanarayana, N., V. Visalakshmi, Subhra Mukherjee and Roy, S.K. 2018. Genetic Variability, Inter-Relationship and Path Analysis for Seed Yield and It's Contributing Traits in Roselle (Hibiscus sabdariffa L.) Over Six Environments. Int.J.Curr.Microbiol.App.Sci. 7(01): 720-732. doi: https://doi.org/10.20546/ijcmas.2018.701.087 